J. Lake Sci. (湖泊科学) , 2012, 24(6): 829-837

http: //www. jlakes.org. E-mail : jlakes@niglas.ac.cn

(C) 2012 by Journal of Lake Sciences

\title{
太湖上游低山丘陵地区不同用地类型氮、磷收支平衡特征"
}

\author{
韩 莹 ${ }^{1,2}$, 李恒鹏 ${ }^{* * *}$, 聂小飞 ${ }^{1,2}$, 徐昔保 ${ }^{1}$ \\ ( 1 : 中国科学院南京地理与湖泊研究所, 湖泊与环境国家重点实验室, 南京 210008) \\ (2: 中国科学院研究生院, 北京 100049)
}

\begin{abstract}
摘 要: 不同用地类型的土壤氮、磷收支平衡决定了氮、磷在土壤的富集, 进一步影响氮、磷的流失强度, 分析该过程有助 于揭示不同用地类型对区域的环境效应. 以位于太湖上游低山丘陵地区的天目湖流域为研究区, 采用农户调查问卷、土 壤和植被生物量实验分析、文献调研和氮、磷表观平衡模型的方法, 选择研究区的茶园、水田、马尾松林和竹林四种典型 用地类型, 系统分析了氮、磷的输人要素, 包括肥料输人、大气沉降、秥秆返田/枯枝落叶、生物固氮、人畜排泄物返田, 以 及输出要素,包括植物生长吸收、氨挥发、反硝化, 并比较不同用地类型氮、磷收支特征. 在此基础上进一步与土壤表层 氮、磷含量比较, 揭示太湖流域上游丘陵山区主要用地类型的水环境效应. 研究结果显示: 土壤氮、磷盈余量大小顺序为 茶园 > 水田 > 马尾松林>竹林, 分别是 648.6、248.9、115.5 53.6 kgN/ $\left(\mathrm{hm}^{2} \cdot \mathrm{a}\right)$ 和 319.9、29.7、1.2 和 $-3.4 \mathrm{kgP} /\left(\mathrm{hm}^{2} \cdot \mathrm{a}\right)$; 氮、磷利用效率以竹林最高, 茶园的氮、磷利用效率均最低, 仅为 $15.0 \%$ 和 $3.1 \%$; 土壤氮盈余量与表层氮含量未能呈现出 一致的关系, 土壤磷盈余量与表层磷含量比较类似, 并由此得出竹林比马尾松林更有利于水环境保护, 而茶园对水环境 的不利影响超过水田.
\end{abstract}

关键词: 太湖上游; 丘陵地区;用地类型;氮磷平衡; 茶园; 天目湖流域

\section{Nitrogen and phosphorus budget of different land use types in hilly area of Lake Taihu up- per-river basin}

\author{
HAN Ying ${ }^{1,2}$, LI Hengpeng ${ }^{1}$, NIE Xiaofei ${ }^{1,2} \&$ XU Xibao ${ }^{1}$ \\ (1: State Key Laboratory of Lake Science and Environment, Nanjing Institute of Geography and Limnology, Chinese Academy \\ of Sciences, Nanjing 210008, P. R. China) \\ (2: Graduate University of Chinese Academy of Sciences, Beijing 100049, P. R. China)
}

Abstract: The enrichment of nitrogen and phosphorus in soil depends on the soil nitrogen and phosphorus budget of different land
use types, which can also influence the strength of nitrogen and phosphorus loss. Understanding this process can help us to know
its regional environment effect of different land use types. The study area is Lake Tianmu Basin, located in the hilly area of Lake
Taihu upper-river basin. We calculated the soil nitrogen and phosphorus budget of different land use types by questionnaire, exper-
imental analysis of soil and biomass, literature investigation and soil apparent balance model, and chose four land use types, inclu-
ding tea garden, paddy fields, masson pine and bamboo forest. We made a systematic analysis of the import and export elements of
nitrogen and phosphorus. The import elements included fertilizer, atmospheric deposition, the straw returned to field or dry bran-
ches and leaves, biological nitrogen fixation and manure. The export elements included plant absorption, ammonia volatilization
and denitrifying. The above analysis can reveal the water environmental effect of mainly land use types in hilly area of Lake Taihu
upper-river basin by comparing with the soil nitrogen and phosphorus content. Results show that the order of soil nitrogen and phos-
phorus surplus are tea garden, paddy field, masson pine and bamboo forest, with the values of $648.6,248.9,115.5,53.6$
$\mathrm{kgN} /\left(\right.$ hm ${ }^{2}$ - a) and $319.9,29.7,1.2$, $-3.4 \mathrm{kgP} /\left(\mathrm{hm}^{2} \cdot\right.$ a), respectively. The nitrogen and phosphorus utilization efficiency
of bamboo forest is the highest, while tea garden is the lowest one, only $15.0 \%$ and $3.1 \%$. The soil nitrogen surplus and nitrogen

* 国家自然科学基金项目 $(41030745,40871238)$ 、中国科学院知识创新工程重要方向项目 (KZCX2-YW-Q10-3) 和国 家重点基础研究发展计划“973”项目 (2008CB418106)联合资助. 2012-01-04 收稿;2012-04-23 收修改稿. 韩 莹,女,1986 年生,硕士研究生;E-mail : hanyingcici@ 126. com.

** 通信作者;E-mail:hpli@ niglas. ac. cn. 
content failed to present a consistent relationship although the soil phosphorus surplus and phosphorus content is similar. This shows that the bamboo forest is more advantageous to the water environmental protection than masson pine, and the tea garden is worse to the water environmental protection than paddy fields.

Keywords: Lake Taihu upper-river basin; hilly area; land use; nitrogen and phosphorus budget; tea garden; Lake Tianmu Basin

人类耕作活动已经改变了自然界的氮、磷平衡, 导致氮、磷流失量增加并带来一系列生态与环境的负面 影响, 如温室气体 $\mathrm{N}_{2} \mathrm{O}$ 排放量增加、臭氧层被破坏、酸雨、水体富营养化、地下水 $\mathrm{NO}_{3}^{-}$污染等, 这些问题是当 前世界各国普遍面临的环境灾害 ${ }^{[1]}$, 已成为土壤学、环境学和生态学等相关领域的研究热点. 早在 $1970 \mathrm{~s}$, 氮、磷流失引发的环境问题逐渐引起研究者的关注, 最早的研究较多地关注于提高肥料利用效率、增加土壤 系统生产力以及研究化肥的施用量与流失量的关系 ${ }^{[24]}$. 目前则更多地关注农田土壤氮、磷循环的环境效 应, 并从土壤系统氮、磷输人输出的整体过程出发, 应用系统方法分析土壤氮、磷动态平衡的变化过程. 其中 具有代表性的是 $\mathrm{OECD}$ 与 FAO 依托区域及全球的农业统计数据平台 ${ }^{[5]}$, 建立了农田生态系统氮、磷收支要 素平衡计算方法, 并得到了较为广泛的应用 ${ }^{[6-8]}$. 国外学者使用该方法对全球农业土壤氮、磷的表观平衡进 行计算 ${ }^{[9]}$, 近年来我国学者也针对全国或区域的土壤氮、磷平衡开展了大量的研究 ${ }^{[10-12]}$, 揭示出我国 $1960 \mathrm{~s}$ 之后化肥施用量逐渐增加, 到 $1970 \mathrm{~s}$ 收支接近平衡 ${ }^{[13-14]}$, 之后农业化肥的大量施用, 导致土壤氮、磷大量盈 余, 对地表及地下水质产生较大的负面影响 ${ }^{[15-17]}$. 从已有的研究来看, 土壤氮、磷平衡过程目前研究的重点 是农业系统, 研究手段主要为农田尺度氮、磷基本平衡过程的实测研究, 或者通过统计数据开展的以行政区 为基本单元的收支平衡计算.

我国是以丘陵或山地为主的国家, 尤其是水热条件充足、经济相对发达的东南地区, 地形地貌以丘陵山 区为主, 近年来随着人地关系的日趋紧张, 丘陵地区的林地向茶园、果园转变的开发迅速发展, 这些开发对 土壤氮、磷收支平衡以及可能产生的环境效应尚不清楚, 因此有必要开展深人的研究. 本文针对以上问题, 以太湖上游天目湖流域为研究区, 综合应用农户调查、土壤氮、磷测定、植被生物量测定、文献调研和氮、磷 表观平衡计算方法, 选择该区域的主要用地类型, 分析比较不同用地类型氮、磷平衡特征和差异, 探讨丘陵 山区开发对环境的潜在影响.

\section{1 研究区概况}

研究区选择位于太湖宜溧河水系上游的天目湖流域 (图 1a), 面积为 $244 \mathrm{~km}^{2}$, 地貌类型以低山丘陵为 主, 地势北低南高, 高程 $2 \sim 531 \mathrm{~m}$. 气候属北亚热带季风气候, 四季分明, 多年平均气温为 $16.6^{\circ} \mathrm{C}$, 平均降雨 量为 $1142 \mathrm{~mm}$. 地带性土壤为黄棕壤, 分布在低山山顶或缓坡、山麓地区石英砂岩残积、坡积物上, 微酸性, 保 水保肥性差, 易被水冲刷导致水土流失, 表层有机质含量约为 $1.9 \%$; 山间谷地和山间平原发育有渗育型水 稻土, 母质为洪积、冲积物, 土层中含有粗砂粒, $60 \mathrm{~cm}$ 以下土层出现砾石层. 天目湖流域拥有沙河与大溪两 座国家级大型水库, 功能以饮用水源、旅游和农业灌溉为主, 承担溧阳市 60 万人口的饮用水源地, 因此天目 湖的水环境保护工作非常重要. 目前流域土地利用以林地、耕地、茶园、建设用地、水体为主, 其中林地面积 占 $37.8 \%$ (主要包括竹林、马尾松林和混交林), 耕地占 $23.6 \%$, 茶园占 $9.3 \%$, 建设用地仅占 $4.3 \%$ (图 $1 \mathrm{~b}$ ). 不同土地利用类型植被覆盖度相差较大, 林地平均植被覆盖度为 $82 \%$; 农作物平均植被覆盖度较低, 为 $68 \%$; 茶园植被覆盖度为 $70 \%$, 低于竹林和马尾松林, 尤其是近 $1 \sim 4 \mathrm{a}$ 新开发的茶园, 覆盖度仅为 $41 \%$.

\section{2 研究方法与参数获取}

不同用地类型的土壤氮、磷收支平衡决定了氮、磷在土壤中的富集, 进一步影响氮、磷随径流流失的强 度, 分析该过程有助于揭示不同用地类型对区域的环境效应. 本研究主要选择天目湖流域的林地、耕地和茶 园为研究对象, 其中林地选择竹林和马尾松林, 耕地选择水田. 氮、磷收支平衡过程包括人为输人、大气沉 降、生物枯枝落叶输人、生物生长输出、反硝化和氨挥发氮损失等.

\section{1 氮、磷平衡计算方法}

土壤的氮、磷平衡的核算采用系统收支平衡法. 


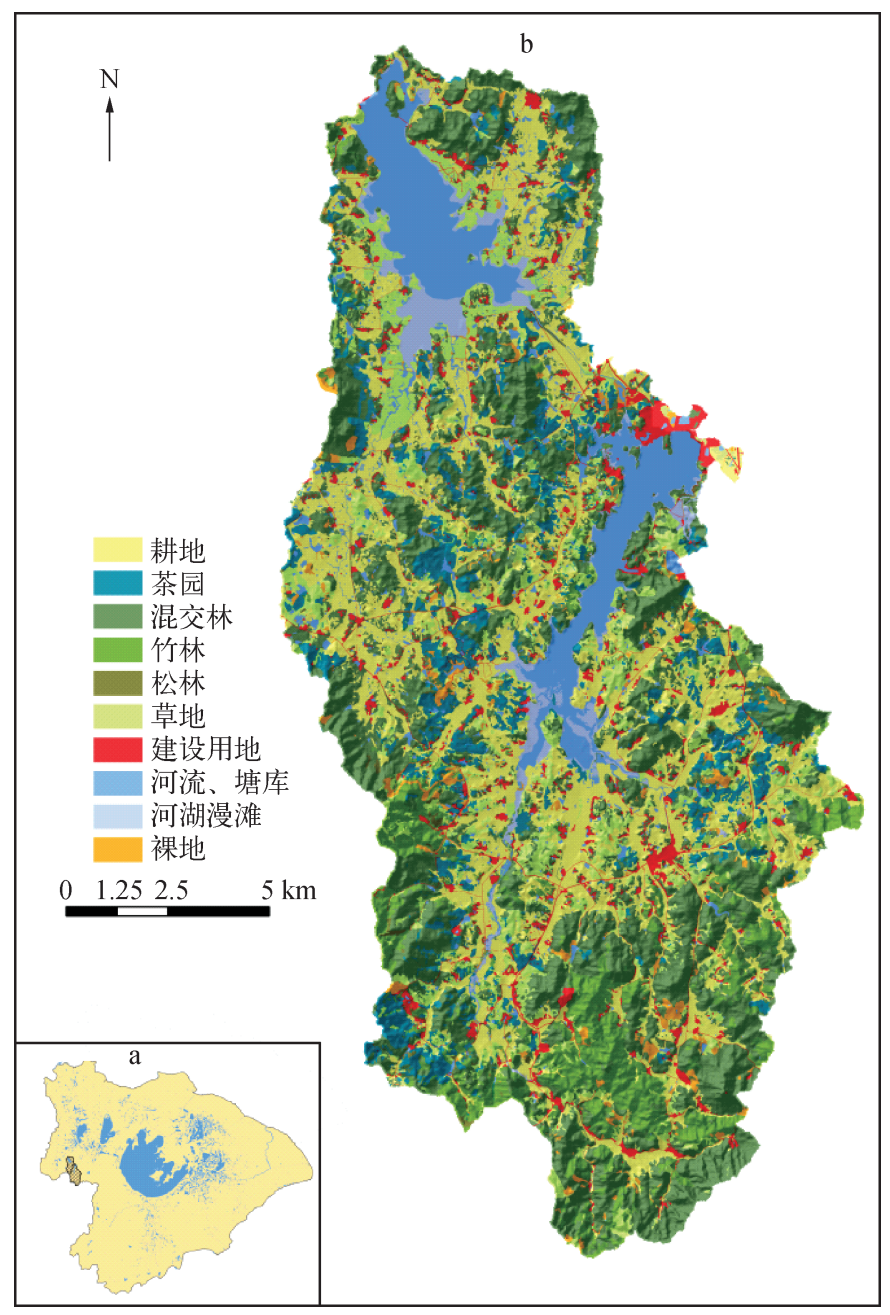

图 1 天目湖流域位置 (a) 及土地利用类型 (b)

Fig. 1 Location(a) and land use types(b) of Lake Tianmu Basin

农田与茶园氮、磷平衡计算方法为:

$$
\begin{gathered}
N_{\text {budget }}=N_{\text {input }}-N_{\text {output }}=\left(N_{\text {fert }}+N_{\text {manu }}+N_{\text {depo }}+N_{\text {resi }}+N_{\text {fix }}\right)-\left(N_{\text {vola }}+N_{\text {deni }}+N_{\text {harv }}\right) \\
P_{\text {budget }}=P_{\text {input }}-P_{\text {output }}=\left(P_{\text {fert }}+P_{\text {manu }}+P_{\text {depo }}+P_{\text {resi }}\right)-P_{\text {harv }}
\end{gathered}
$$

竹林与马尾松林氮、磷平衡计算方法为:

$$
\begin{gathered}
N_{\text {budget }}=N_{\text {input }}-N_{\text {output }}=\left(N_{\text {depo }}+N_{\text {resi }}+N_{\text {fix }}\right)-\left(N_{\text {deni }}+N_{\text {bio }}\right) \\
P_{\text {budget }}=P_{\text {input }}-P_{\text {output }}=\left(P_{\text {depo }}+P_{\text {resi }}\right)-P_{\text {bio }}
\end{gathered}
$$

式中, $N_{\text {budget }} P_{\text {budget }}$ 代表氮、磷平衡量, $N_{\text {input }} P_{\text {input }}$ 代表氮、磷输人量, $N_{\text {output }} 、 P_{\text {output }}$ 代表氮、磷输出量, $N_{\text {fert }} 、 P_{\text {fert }}$ 代 表化肥施用, $N_{\text {manu }} 、 P_{\text {manu }}$ 代表有机肥, $N_{\text {depo }} 、 P_{\text {depo }}$ 代表大气沉降, $N_{\text {fix }}$ 代表生物固氮, $N_{\text {resi }} 、 P_{\text {resi }}$ 代表农作物返茬或 植物枯枝落叶, $N_{\text {vola }}$ 代表氨挥发, $N_{\text {deni }}$ 代表反硝化, $N_{\text {harv }}, P_{\text {harv }}$ 代表作物收获, $N_{\text {bio }}, P_{\text {bio }}$ 代表植物生长. 这里氮、磷 平衡指系统平衡, 不包括地表径流和渗漏量, 森林土壤磷循环输人项还包括岩石矿化, 输出项还包括风蚀, 但由于岩石矿化和风蚀是一个缓慢的过程,这里忽略不计. 


\section{2 农户生产与生活调查}

2010 年 10 月在天目湖流域针对农户进行问卷调查, 调查内容包括:农作物种类、产量; 农户耕作面积; 每户耕地的施肥结构; 家畜种类和产量; 农户售出和自己消费的家畜量; 常住人口; 售出的农产品类型与数 量; 人畜排泄物处理方法等. 本次共调查典型农户 15 户, 大规模茶园 1 家. 通过这些调查, 获取农田施用的化 肥 $\left(N_{\text {fert }} P_{\text {fert }}\right)$ 、有机肥 $\left(N_{\text {manu }} 、 P_{\text {manu }}\right)$ 、农作物种类和产量 $\left(N_{\text {harv }} 、 P_{\text {harv }}\right)$.

根据问卷调查结果可知, 天目湖流域主要施肥的用地类型有稻一麦 (油) 轮作水田和茶园, 施用化肥主要 种类为尿素和复合肥, 有机肥主要包括菜饼、鸡粪等有机肥料, 其中水田主要是人畜排泄返田, 根据调查问 卷中每户的常住人口数和畜禽养殖数量乘以年氮、磷排放系数并乘以返田率计算得到 (国家环境保护总局 推荐的排泄系数: 人排泄系数为 $4 \mathrm{kgN} / \mathrm{a} 、 2 \mathrm{kgP} / \mathrm{a}$; 牛 $61.1 \mathrm{kgN} /($ 头 $\cdot \mathrm{a}$ )、10.07 $\mathrm{kgP} /($ 头 $\cdot \mathrm{a}$ );

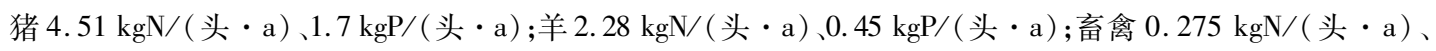
$0.115 \mathrm{kgP} /($ 头 $\cdot \mathrm{a})$; 茶园的有机肥则是调查的茶园施肥制度. 该流域农村每户都有生态户则, 因此人畜排泄 物排放量少, 调查的返田率约为 $10 \%$. 不同作物和种植模式下的肥料施用结构见表 1 . 就施肥量而言, 茶园 > 油菜 $>$ 水稻 $>$ 小麦; 就种植模式而言, 茶园 $>$ 稻 - 油轮作水田 $>$ 稻-麦轮作水田. 水田施用的氮肥主要来源于 尿素, 约占全部氮肥的 $85 \%$, 磷肥来源于复合肥和有机肥, 同时可以看出, 水田的氮肥施用量远大于磷肥, 茶 园的施氮量比磷肥高 1 倍.

表 1 不同作物和种植模式的施肥结构 $\left(\mathrm{kg} /\left(\mathrm{hm}^{2} \cdot \mathrm{a}\right)\right)^{*}$

Tab. 1 Fertilization structure of different crops and planting modes

\begin{tabular}{|c|c|c|c|c|c|c|}
\hline 肥料种类 & 水稻 & 油菜 & 小麦 & 稻一麦 & 稻一油 & 茶园 \\
\hline 尿素 & $\begin{array}{c}551 \\
(450 \sim 1250)\end{array}$ & $\begin{array}{c}537 \\
(450 \sim 625)\end{array}$ & $\begin{array}{c}351 \\
(180 \sim 635)\end{array}$ & $\begin{array}{c}902 \\
(630 \sim 1885)\end{array}$ & $\begin{array}{c}1088 \\
(900 \sim 1875)\end{array}$ & 0 \\
\hline 复合肥 & $\begin{array}{c}304 \\
(150 \sim 563)\end{array}$ & $\begin{array}{c}440 \\
(413 \sim 469)\end{array}$ & $\begin{array}{c}330 \\
(180 \sim 469)\end{array}$ & $\begin{array}{c}634 \\
(330 \sim 1032)\end{array}$ & $\begin{array}{c}744 \\
(563 \sim 1023)\end{array}$ & 0 \\
\hline 有机肥 & 0 & 0 & 0 & 0 & 0 & 18000 \\
\hline 折纯氮 & $\begin{array}{c}445 \\
(82 \sim 531)\end{array}$ & $\begin{array}{c}315 \\
(270 \sim 360)\end{array}$ & $\begin{array}{c}247 \\
(111 \sim 360)\end{array}$ & $\begin{array}{c}692 \\
(193 \sim 891)\end{array}$ & $\begin{array}{c}760 \\
(352 \sim 891)\end{array}$ & 959 \\
\hline 折纯磷 & $\begin{array}{c}18 \\
(10 \sim 69)\end{array}$ & $\begin{array}{c}29 \\
(27 \sim 30)\end{array}$ & $\begin{array}{c}22 \\
(12 \sim 30)\end{array}$ & $\begin{array}{c}40 \\
(22 \sim 99)\end{array}$ & $\begin{array}{c}47 \\
(37 \sim 99)\end{array}$ & 325 \\
\hline
\end{tabular}

* 尿素折氮率为 $46.4 \%$; 复合肥折氮率为 $15.0 \%$, 折磷率为 $6.5 \%$; 菜饼折氮率为 $9.6 \%$, 折磷率为 $2.5 \%$; 鸡粪折氮率为 $1.0 \%$, 折磷率为 $0.4 \%$; 猪粪折氮率为 $1.1 \%$, 折磷率为 $0.4 \%$ (麻类作物营养与施肥网 http: //www. fibercrops. com); 表中 数据为平均值, 括号内的数据为范围.

\section{3 不同植被类型生物量测定}

植被生长吸收是氮、磷输出的主要途径, 为获得准确的参数, 对天目湖流域所选用地类型内进行采样, 并且分别测量其生物量和调落物的氮、磷含量, 方法如下:竹林和马尾松林的生物量采样是在面积较大且连 续均一的样地中设立 $10 \mathrm{~m} \times 10 \mathrm{~m}$ 的样方, 测定每一棵样本的胸径、树高、树龄, 采集不同部位的样品, 并对林 下草本设置 $1 \mathrm{~m} \times 1 \mathrm{~m}$ 的样方采用收割法收获样方内所有草本植被, 回到室内利用生物量方程计算生物量并 测定氮、磷含量; 茶园则是采用收割法收获一株/丛 (按标准木方法), 样方面积为 $1 \mathrm{~m} \times 1 \mathrm{~m}$, 目数样方内的茶 叶的株数/丛数, 回到实验室采用烘干称重 $\left(80^{\circ} \mathrm{C}, 24 \mathrm{~h}\right)$, 计算样方生物量和氮、磷含量; 水稻田生长相对比 较均质, 因此选择设置采样大小为 $30 \mathrm{~cm} \times 30 \mathrm{~cm}$, 采用收割法收获样方内所有植被, 回到实验室烘干称重 $\left(80^{\circ} \mathrm{C}, 24 \mathrm{~h}\right)$, 计算样方生物量和氮、磷含量. 调落物比例则是通过收集调落物后采用类似方法获得. 测定结 果与已有研究结果 ${ }^{[18-23]}$ 进行对比, 发现差异不大, 测试结果见表 2.

\section{4 大气沉降氮、磷测定}

大气沉降是土壤氮、磷输人的重要来源之一, 尤其对林地的氮、磷来源具有较大的贡献 ${ }^{[24]}$, 为得到研究 区准确的大气沉降量, 本课题组在流域内布设了大气沉降仪. 干沉降样品每月收集一次; 湿沉降样品每下一 次雨收集一次,按日进行收集, 当日 9:00 至次日 9:00 为一个湿沉降日,收集区间为 2011 年 1 月 1 日至 12 
月 31 日一个完整年度. 根据监测结果, 该流域大气沉降率为 $96.8 \mathrm{kgN} /\left(\mathrm{hm}^{2} \cdot \mathrm{a}\right) 、 3.8 \mathrm{kgP} /\left(\mathrm{hm}^{2} \cdot \mathrm{a}\right)$.

表 2 不同植被类型生态参数*

Tab. 2 Ecological parameters of different vegetation types

\begin{tabular}{lcccccc}
\hline 参数 & 稻谷 & 小麦 & 油菜 & 茶树 & 毛竹 & 马尾松 \\
\hline 氮含量 $/ \%$ & 2.1 & 3.0 & 5.8 & 2.7 & 0.5 & 0.5 \\
磷含量 $/ \%$ & 0.28 & 0.16 & 0.5 & 0.17 & 0.38 & 0.42 \\
生物量 $/\left(\mathrm{kg} /\left(\mathrm{m}^{2} \cdot \mathrm{a}\right)\right)$ & 4.77 & 1.01 & 0.73 & 0.61 & 2.21 & 0.51 \\
& $(4.57 \sim 4.98)$ & $(0.88 \sim 1.14)$ & $(0.66 \sim 0.80)$ & $(0.53 \sim 0.75)$ & $(1.89 \sim 4.21)$ & $(0.42 \sim 0.59)$ \\
调落物比例 $/ \%$ & - & - & - & 15 & 44 & 13 \\
\hline
\end{tabular}

*小麦和油料生物量采用问卷调查的产量和草谷比推算得出.

\section{5 实验参数的获取}

不同用地类型的生物固氮 $\left(N_{\mathrm{fix}}\right)$ 、氨挥发 $\left(N_{\mathrm{vola}}\right)$ 、反硝化 $\left(N_{\mathrm{deni}}\right)$ 等参数的确定主要通过查阅文献, 参数的 选择考虑地区代表性以及主流研究机构成果等. 生物固氮的参数分别取水田 $45.0 \mathrm{kgN} /\left(\mathrm{hm}^{2} \cdot \mathrm{a}\right)^{[25]}$ 、茶园 $22.0 \mathrm{kgN} /\left(\mathrm{hm}^{2} \cdot \mathrm{a}\right)^{[24]}$ 、竹林 $12.5 \mathrm{kgN} /\left(\mathrm{hm}^{2} \cdot \mathrm{a}\right)^{[26]}$ 、马尾松林 $47.0 \mathrm{kgN} /\left(\mathrm{hm}^{2} \cdot \mathrm{a}\right)^{[23]}$. 另外, 农作物的残 茬返田率以 $24.3 \%{ }^{[27]}$ 计算. 氨挥发和反硝化参数考虑太湖地区施肥强度进行选取 (表 3 ).

表 3 文献引用的氨挥发和反硝化参数

Tab. 3 The ammonia volatilization and denitrification parameters of the reference in the literature

\begin{tabular}{|c|c|c|c|c|c|c|c|c|}
\hline 用地类型 & $\begin{array}{c}\text { 化肥氨挥发/ } \\
\%\end{array}$ & 参考文献 & $\begin{array}{c}\text { 化肥反硝化 } \\
\%\end{array}$ & 参考文献 & $\begin{array}{c}\text { 有机肥氨挥发 } \\
\%\end{array}$ & 参考文献 & $\begin{array}{l}\text { 机肥反硝化 } \\
\%\end{array}$ & 参考文献 \\
\hline 茶园 & - & - & - & - & 20 & {$[35]$} & 20 & {$[35]$} \\
\hline 水田 & $\begin{array}{l}\text { 稻:29.9 } \\
\text { 麦:2.1 }\end{array}$ & $\begin{array}{l}{[28]} \\
{[30]}\end{array}$ & $\begin{array}{l}\text { 稻: } 35.3 \\
\text { 麦:0.6 }\end{array}$ & $\begin{array}{l}{[29]} \\
{[31]}\end{array}$ & - & - & - & - \\
\hline 马尾松林 & 0 & {$[24]$} & $6.1 \mathrm{kgN} /\left(\mathrm{hm}^{2} \cdot \mathrm{a}\right)$ & {$[32]$} & - & - & - & - \\
\hline 竹林 & 0 & {$[24]$} & $16.6 \mathrm{kgN} /\left(\mathrm{hm}^{2} \cdot \mathrm{a}\right)$ & [33-34] & - & - & - & - \\
\hline
\end{tabular}

\section{6 不同用地类型土壤理化性质测定}

比较不同用地类型的氮、磷收支平衡与土壤氮、磷含量的关系有助于间接认识氮、磷随径流流失的强度 及其引发的水环境效应, 因此有必要测定不同用地类型土壤的氮、磷含量. 针对本文研究的茶园、水田、马尾 松林和竹林, 分别在不同地点、地貌部位采集土壤样品, 目的是使采集的土壤更有代表性, 共计采集 60 个样 点, 其中水田 15 个、茶园 5 个、竹林 5 个、马尾松林 6 个, 其余为果园、混交林等 (在文章中没有涉及到), 水 田土壤为渗育型水稻土, 茶园和林地的土壤类型多为黄棕壤. 样品风干后分别以开氏消煮法测定全氮含量, 以 $2 \mathrm{~mol} / \mathrm{L} \mathrm{KCl}$ 浸提及比色法测定土壤速效氮含量, 以酸溶-钿锑抗比色法测定土壤全磷含量, 以 $0.5 \mathrm{~mol} / \mathrm{L}$ $\mathrm{Na}_{2} \mathrm{CO}_{3}$ 浸提法及钼蓝比色法测定土壤速效磷含量, 对不同用地类型土样分别进行统计分析, 结果见表 4 .

表 4 天目湖流域不同用地类型土壤养分特征 $(0 \sim 5 \mathrm{~cm})$

Tab. 4 Soil nutrient of different land use types in Lake Tianmu Basin

\begin{tabular}{ccccc}
\hline 用地类型 & 全氮 $/(\mathrm{g} / \mathrm{kg})$ & 速效氮 $/(\mathrm{mg} / \mathrm{kg})$ & 全磷 $/(\mathrm{g} / \mathrm{kg})$ & 速效磷 $/(\mathrm{mg} / \mathrm{kg})$ \\
\hline 茶园 & $3.21 \pm 0.83$ & $54.07 \pm 26.65$ & $0.40 \pm 0.13$ & $130.11 \pm 70.12$ \\
水田 & $3.27 \pm 0.41$ & $62.40 \pm 5.21$ & $0.41 \pm 0.03$ & $63.18 \pm 33.67$ \\
马尾松林 & $3.00 \pm 0.74$ & $44.75 \pm 10.67$ & $0.23 \pm 0.03$ & $32.72 \pm 16.90$ \\
竹林 & $4.47 \pm 0.76$ & $90.23 \pm 17.37$ & $0.24 \pm 0.16$ & $17.83 \pm 12.56$ \\
\hline
\end{tabular}

\section{3 结果与讨论}

依据以上计算方法和参数, 分别计算茶园、水田、马尾松林和竹林的氮、磷收支平衡, 计算结果见表 5 、 
表 6.

\section{1 不同用地类型氮、磷输入强度比较}

氮、磷收支平衡计算结果可以看出, 天目湖流域不同用地类型氮、磷输人总量和来源结构均有显著差异 (表 5 、表 6). 其中氮输人总量以茶园和水田最高, 平均输人总量分别为 $1101.4 、 1096.8 \mathrm{kgN} /\left(\mathrm{hm}^{2} \cdot \mathrm{a}\right)$, 约是 竹林 $\left(179.8 \mathrm{kgN} /\left(\mathrm{hm}^{2} \cdot \mathrm{a}\right)\right)$ 和马尾松林 $\left(147.2 \mathrm{kgN} /\left(\mathrm{hm}^{2} \cdot \mathrm{a}\right)\right)$ 的 6 倍多. 从氮素输人来源的结构看, 水田 以化肥施用为主, 占 $60.4 \%$, 其次是秸秆返田, 约占 $26.6 \%$; 茶园氮输人总量以有机肥为主, 占 $87.0 \%$, 而枯 枝落叶返回的氮仅占 $2.2 \%$; 竹林的氮输人主要为大气沉降, 占 $53.9 \%$, 其次是枯枝落叶和生物固氮, 分别占 $26.9 \%$ 和 $19.2 \%$; 马尾松林的氮输人也以大气沉降为主, 占 $65.8 \%$, 其次是生物固氮, 占 $31.9 \%$, 由于马尾 松林生长较慢, 属于常绿针叶林, 枯枝落叶返回的氮素也很少, 仅占 $2.2 \%$.

磷素输人与氮素类似, 茶园的平均磷输人总量最高, 为 $330.3 \mathrm{kgP} /\left(\mathrm{hm}^{2} \cdot \mathrm{a}\right)$, 是水田 $\left(64.1 \mathrm{kgP} /\left(\mathrm{hm}^{2} \cdot \mathrm{a}\right)\right)$ 的 5 倍, 竹林 $\left(9.5 \mathrm{kgP} /\left(\mathrm{hm}^{2} \cdot \mathrm{a}\right)\right)$ 的 35 倍, 马尾松林 $\left(4.2 \mathrm{kgP} /\left(\mathrm{hm}^{2} \cdot \mathrm{a}\right)\right)$ 的 79 倍. 茶园磷输人以有机肥为主, 占输人总量的 $97.4 \%$; 水田磷输人仍以化肥为主, 主要来源于复合肥, 占输人总量的 $62.1 \%$, 其次是秸秆返 田, 约为 $27.0 \%$; 竹林的主要磷素来源为大气沉降和枯枝落叶, 分别占 $40.0 \%$ 和 $60.0 \%$; 马尾松林的主要磷 素来源为大气沉降, 占总量的 $90.5 \%$.

表 5 不同用地类型土壤氮平衡 $\left(\mathrm{kgN} /\left(\mathrm{hm}^{2} \cdot \mathrm{a}\right)\right)$

Tab. 5 Soil nitrogen budget of different land use types

\begin{tabular}{|c|c|c|c|c|c|c|c|c|c|}
\hline \multirow{2}{*}{$\begin{array}{l}\text { 用地 } \\
\text { 类型 }\end{array}$} & \multicolumn{5}{|c|}{ 输人量 } & \multicolumn{3}{|c|}{ 输出量 } & \multirow[b]{2}{*}{ 盈余量 } \\
\hline & 化肥 & $\begin{array}{l}\text { 大气 } \\
\text { 沉降 }\end{array}$ & $\begin{array}{l}\text { 生物 } \\
\text { 固氮 }\end{array}$ & $\begin{array}{l}\text { 秸秆还田/ } \\
\text { 枯枝落叶 }\end{array}$ & $\begin{array}{l}\text { 有机肥/ } \\
\text { 排泄返田 }\end{array}$ & $\begin{array}{c}\text { 农作物收获/ } \\
\text { 植物生长 }\end{array}$ & 氨挥发 & 反硝化 & \\
\hline 茶园 & 0 & 96.9 & 22.0 & $\begin{array}{c}24 \\
(21 \sim 30)\end{array}$ & 958.5 & $\begin{array}{c}165.2 \\
(122.6 \sim 172.2)\end{array}$ & 191.7 & 95.9 & $\begin{array}{c}648.6 \\
(637.2 \sim 688.2)\end{array}$ \\
\hline 水田 & $\begin{array}{c}692.3 \\
(193.2 \sim 891.5)\end{array}$ & 96.9 & 45.0 & $\begin{array}{c}255.2 \\
(188.1 \sim 305.6)\end{array}$ & $\begin{array}{c}7.4 \\
(2.5 \sim 13.6)\end{array}$ & $\begin{array}{c}548.0 \\
(305.2 \sim 598.4)\end{array}$ & $\begin{array}{c}139.9 \\
(60.1 \sim 266.0)\end{array}$ & $\begin{array}{c}160.0 \\
(68.3 \sim 315.6)\end{array}$ & $\begin{array}{c}248.9 \\
(92.1 \sim 315.3)\end{array}$ \\
\hline $\begin{array}{l}\text { 马尾 } \\
\text { 松林 }\end{array}$ & 0 & 96.9 & 47.0 & $\begin{array}{c}3.3 \\
(3.1 \sim 3.7)\end{array}$ & 0 & $\begin{array}{c}25.5 \\
(18.3 \sim 29.2)\end{array}$ & 0 & 6.1 & $\begin{array}{c}115.5 \\
(112.3 \sim 122.6)\end{array}$ \\
\hline 竹林 & 0 & 96.9 & 34.6 & $\begin{array}{c}48.3 \\
(41.3 \sim 92.2)\end{array}$ & 0 & $\begin{array}{c}109.6 \\
(52.8 \sim 118.3)\end{array}$ & 0 & 16.6 & $\begin{array}{c}53.6 \\
(42.6 \sim 88.8)\end{array}$ \\
\hline
\end{tabular}

表 6 不同用地类型土壤磷平衡 $\left(\mathrm{kgP} /\left(\mathrm{hm}^{2} \cdot \mathrm{a}\right)\right)$

Tab. 6 Soil phosphorus budget of different land use types

\begin{tabular}{|c|c|c|c|c|c|c|}
\hline \multirow[b]{2}{*}{ 用地类型 } & \multicolumn{4}{|c|}{ 输人量 } & \multirow{2}{*}{$\begin{array}{c}\text { 输出量 } \\
\text { 农作物收获/ } \\
\text { 植物生长 }\end{array}$} & \multirow[b]{2}{*}{ 盈余量 } \\
\hline & 化肥 & 大气沉降 & $\begin{array}{l}\text { 秥秆还田/ } \\
\text { 枯枝落叶 }\end{array}$ & $\begin{array}{l}\text { 有机肥/ } \\
\text { 人畜排泄 }\end{array}$ & & \\
\hline 茶园 & 0 & 3.8 & $\begin{array}{c}1.6 \\
(1.3 \sim 1.9)\end{array}$ & 324.9 & $\begin{array}{c}10.4 \\
(7.6 \sim 10.8)\end{array}$ & $\begin{array}{c}319.9 \\
(312.2 \sim 322.4)\end{array}$ \\
\hline 水田 & $\begin{array}{c}39.8 \\
(22.0 \sim 99.0)\end{array}$ & 3.8 & $\begin{array}{c}15.0 \\
(12.1 \sim 18.6)\end{array}$ & $\begin{array}{c}3.2 \\
(1.1 \sim 5.2)\end{array}$ & $\begin{array}{c}32.1 \\
(25.2 \sim 38.8)\end{array}$ & $\begin{array}{c}29.7 \\
(13.8 \sim 87.8)\end{array}$ \\
\hline 马尾松林 & 0 & 3.8 & $\begin{array}{c}0.4 \\
(0.3 \sim 0.5)\end{array}$ & 0 & $\begin{array}{c}3.0 \\
(2.1 \sim 3.5)\end{array}$ & $\begin{array}{c}1.2 \\
(0.7 \sim 2.0)\end{array}$ \\
\hline 竹林 & 0 & 3.8 & $\begin{array}{c}5.7 \\
(4.6 \sim 6.5)\end{array}$ & 0 & $\begin{array}{c}12.8 \\
(10.5 \sim 14.8)\end{array}$ & $\begin{array}{c}-3.4 \\
(-4.5 \sim-2.1)\end{array}$ \\
\hline
\end{tabular}

\section{2 不同用地类型氮、磷输出强度比较}

比较分析不同用地类型氮、磷的输出要素可以看出, 水田的氮输出总量最高, 为 $847.9 \mathrm{kgN} /\left(\mathrm{hm}^{2} \cdot \mathrm{a}\right)$, 其次是茶园、竹林和马尾松林, 分别为 $452.8 、 126.2$ 和 $31.6 \mathrm{kgN} /\left(\mathrm{hm}^{2} \cdot \mathrm{a}\right)$. 不同用地类型主要氮输出途径 
也各不相同, 水田输出以农作物生长吸收为主, 占输出总量的 $62.4 \%$, 其余为反硝化和氨挥发, 分别占输出 总量的 $20.1 \%$ 和 $17.5 \%$; 茶园氮输出以气态损失为主, 尤其是氨挥发为 $191.7 \mathrm{kgN} /\left(\mathrm{hm}^{2} \cdot \mathrm{a}\right)$, 而反硝化量 为 $95.9 \mathrm{kgN} /\left(\mathrm{hm}^{2} \cdot \mathrm{a}\right)$, 两项气态损失占总输出量的 $63.5 \%$, 而茶树生长输出氮仅占总输出的 $36.5 \%$; 竹林 和马尾松林氮输出均以植物生长输出为主, 但竹林生物量大, 氮输出量大, 为 $109.6 \mathrm{kgN} /\left(\mathrm{hm}^{2} \cdot \mathrm{a}\right)$, 而马尾 松林仅为 $25.5 \mathrm{kgN} /\left(\mathrm{hm}^{2} \cdot \mathrm{a}\right)$, 林地氨挥发很少, 忽略不计, 反硝化在竹林和马尾松林氮的输出总量所占比 例均较小. 磷的输出主要为植被生长的输出, 主要和生物量及植物磷含量有关, 四种用地类型的磷输出量依 次为水田 $>$ 茶园 $\approx$ 竹林 $>$ 马尾松林.

通过比较植物生长吸收的土壤氮、磷输出量与输人总量的关系可以了解不同用地类型的氮、磷利用效 率. 结果显示, 氮、磷利用效率以竹林最高, 氮为 $61 \%$, 磷也得到充分利用; 水田的氮、磷利用效率分别为 $43.4 \%$ 和 $46.5 \%$, 与已有研究结果类似 ${ }^{[36-37]}$; 马尾松林的氮利用率较低, 仅为 $17.3 \%$, 但磷利用率很高, 达到 $71.4 \%$; 茶园的氮、磷利用效率最低,仅为 $15.0 \%$ 和 $3.1 \%$.

\section{3 不同用地类型氮、磷收支平衡的比较}

土壤氮、磷平衡为正时表现为盈余, 为负时表现为亏损, 目前一般表现为盈余. 土壤氮、磷盈余可以提高 土壤肥力, 但也可能导致通过径流损失的氮、磷增加, 进而对水环境产生不利影响. 综合分析 4 种用地类型 的土壤氮、磷收支特征可以看出, 茶园、水田、马尾松林和竹林的土壤氮平衡都以盈余为主, 分别为 648.6、 $248.9 、 115.5 、 53.6 \mathrm{kgN} /\left(\mathrm{hm}^{2} \cdot \mathrm{a}\right)$. 茶园的土壤氮盈余量最高, 主要因为有机肥施用导致的氮输人量大, 但 利用效率低, 而茶园多分布于坡地, 必然导致土壤盈余的氮随径流大量流失; 水田的氮输人总量虽然与茶园 相当, 但是农作物的氮利用率高于茶树, 因此, 水田的氮盈余量仅为茶园的 $1 / 2$, 由此可见丘陵山区茶园对水 环境的影响大于水田; 马尾松林和竹林的氮盈余量均低于茶园和水田, 其中竹林的收支更趋于平衡, 盈余量 仅为茶园的 $1 / 12$, 主要由于竹林生物量大, 对氮的利用率高、循环快, 此外, 这种机制有助于将土壤中易迁移 的无机氮吸收转变为有机氮, 并以调落物形式返还至土壤, 一方面改善了土壤结构, 另一方面有益于土壤中 氮素的长期积累; 马尾松林的生物量相对于竹林较小, 氮利用率较低, 土壤氮盈余量高于竹林. 因此, 竹林相 对于马尾松林可以减少氮的流失,更有利于水环境的保护.

4 种用地类型的土壤磷平衡除竹林略有亏损外,其它 3 种用地类型均以盈余为主, 表现为茶园 > 水田 > 马尾松林, 盈余量分别为 $319.9 、 29.7 、 1.2 \mathrm{kgP} /\left(\mathrm{hm}^{2} \cdot \mathrm{a}\right)$, 该结果从营养盐平衡的角度验证了高志勤 ${ }^{[38]}$ 建 议的毛竹林应合理补充磷素的观点. 土壤磷平衡和氮平衡的差别主要表现为不同用地类型磷的平衡量相差 幅度远大于氮平衡量的相差幅度, 茶园和水田的氮盈余量是马尾松林和竹林的 $3 \sim 12$ 倍, 而磷盈余量是马 尾松林的 $30 \sim 300$ 倍, 二者呈现数量级的差异. 此外, 人为活动影响下的茶园和水田的氮、磷盈余量的相差 幅度也不同, 氮盈余量仅相差 1 倍, 磷盈余量却相差 7 倍, 主要原因是茶园施用的有机肥导致大量磷输人, 水 田施用的化肥中磷输人量相对较少. 同时磷的迁移以颗粒态为主, 多随土壤侵蚀而发生, 在茶园开发初期 (1 4 a), 植被覆盖度不到 50\%, 土壤侵蚀剧烈, 必然导致土壤中的磷大量进人水体, 引发富营养化问题, 因 此,在茶园开发初期,加强水土流失的防治及对磷流失的控制对水环境的保护尤为重要.

\section{4 不同用地类型土壤氮、磷平衡与土壤表层氮、磷含量的比较}

氮、磷在土壤表层的累积一方面与土壤表观氮、磷平衡量有关, 另一方面也与地表氮、磷在降雨径流中 的流失强度有关. 通过比较土壤表层氮、磷含量与表观氮、磷平衡量的关系, 可以间接的了解土壤氮、磷流失 强度及其对水环境的潜在影响.

土壤氮、磷含量并没有与氮、磷盈余量呈现一致的关系 (图 2). 尽管竹林土壤的氮盈余量最低, 但土壤氮 含量最高, 与刘西军等 ${ }^{[39]}$ 和高志勤 ${ }^{[38]}$ 的研究结果相似, 主要因为竹林植被覆盖度最高, 地表枯枝落叶多, 蓄 水能力强, 地表产流较小, 土壤表层的氮素不易随地表径流流失, 由此可见, 竹林有一个高效的氮素累积机 制, 对水环境的不利影响最小. 同样, 马尾松林氮盈余量远小于茶园和水田, 但是三者土壤氮含量接近, 均小 于竹林, 说明其土壤氮流失量远远小于水田和茶园, 但对土壤肥力的保持能力低于竹林. 茶园氮盈余量是水 田的 1.5 倍, 但是土壤氮含量却低于水田, 说明茶园氮流失量大于水田, 主要原因是茶园处于坡地, 植株高 度较小, 植被覆盖度低, 降水拦截能力较弱, 同时地表经常除草造成裸露, 一旦发生降雨冲刷, 必然导致流失 强度大, 由此可知, 茶园土壤氮素表现为高输人、低利用、高流失, 对水环境的威胁最大; 水田土壤氮盈余量 

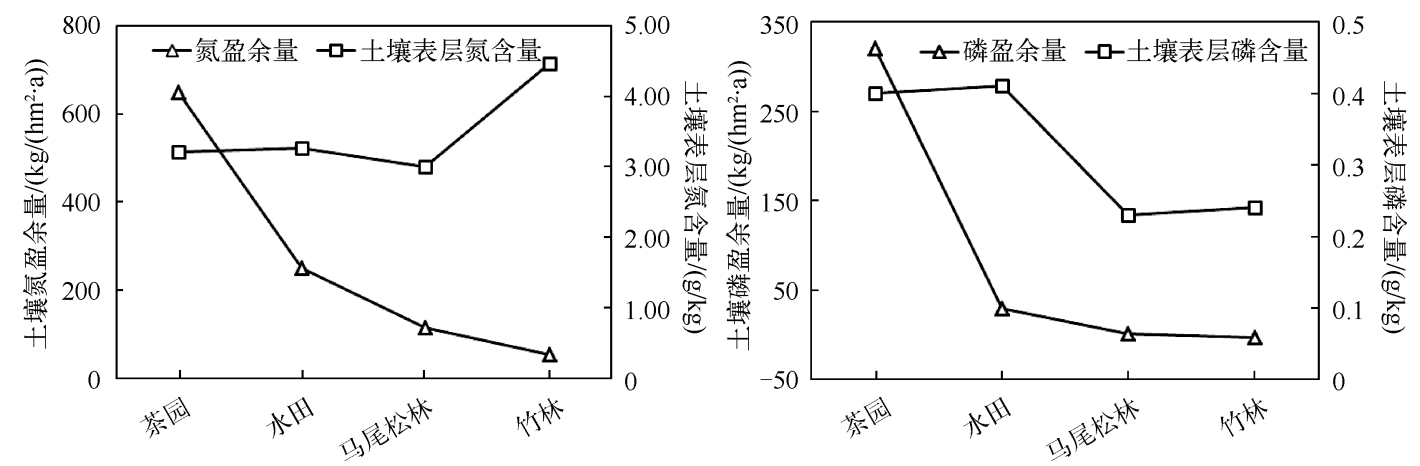

图 2 不同用地类型土壤氮、磷盈余量与表层氮、磷含量比较

Fig. 2 Comparisons of soil nitrogen/phosphorus budget and content of different land use types

较高, 但长期处于水淹状态, 且氮素的迁移以溶解态为主, 淋溶作用强, 经地下水迁移后流失量较大, 因此土 壤氮含量低于竹林, 同时会污染地下水.

磷素随径流的迁移与氮素不同,一般以颗粒态为主, 同时, 不同用地类型磷的平衡量相差幅度远大于氮 平衡量的相差幅度, 不同用地类型土壤磷素的盈余量与表层磷含量特征明显有别于氮素, 茶园和水田土壤 磷含量高于马尾松林和竹林, 主要由于前两者的磷盈余量远远高于后两种用地类型 (图 2). 茶园土壤的磷含 量略低于水田, 但是磷盈余量最高, 为水田的 8 倍, 主要由于茶园在坡地, 植被覆盖度较低, 土壤侵蚀较严 重, 土壤表层中的磷素容易随土壤侵蚀流失, 而天目湖流域的水田处于山间平原或冲地, 磷素不容易流失, 因此,水田的土壤磷含量最高, 茶园的磷流失量也非常显著.

以上分析可以看出, 天目湖流域的茶园开发, 会使该土地利用类型从原本的低盈余、高积累、低流失模 式转变为高盈余、低利用、高流失的模式, 必然会对流域水质造成威胁. 同时, 由于竹林高效的氮累积机制, 土壤表层含氮量较高,一旦被破坏被开发为茶园, 氮流失量会显著增加, 严重威胁水库源头的水质, 这也可 能是目前流域水体氮浓度高的原因之一.

\section{4 结论}

本研究通过对天目湖流域的不同用地类型的土壤氮、磷收支平衡计算及其与土壤表层氮、磷含量的比 较后, 得出以下结论:

1) 太湖上游低山丘陵地区不同用地类型的土壤氮、磷盈余量自高而低依次为茶园 > 水田 >马尾松林 > 竹林, 其中氮盈余量分别为 $648.6 、 248.9 、 115.5 、 53.6 \mathrm{kgN} /\left(\mathrm{hm}^{2} \cdot \mathrm{a}\right)$, 磷盈余量分别为 $319.9 、 29.7 、 1.2$ 、 $-3.4 \mathrm{kgP} /\left(\mathrm{hm}^{2} \cdot \mathrm{a}\right)$. 茶园和水田的氮、磷输人主要来自于化肥或有机肥料.

2) 不同用地类型的氮、磷利用效率以竹林最高, 氮素吸收率高达 $61 \%$, 磷也得到充分利用; 水田的氮、 磷利用效率分别为 $43.4 \%$ 和 $46.5 \%$; 马尾松林的氮利用率仅为 $17.3 \%$, 但磷利用率很高, 达到 $71.4 \%$; 茶园 的氮、磷利用效率均最低，仅为 $15.0 \%$ 和 $3.1 \%$.

3) 通过比较不同用地类型土壤氮、磷盈余量与土壤表层氮、磷含量揭示出:竹林和马尾松林均有较高的 氮、磷累积机制, 但竹林更强, 因此在天目湖流域竹林比马尾松林更有利于水环境保护; 茶园和水田流失量 均比竹林和马尾松林高, 而茶园由于坡度大, 植被覆盖度低, 因此较水田而言其随地表径流的氮、磷流失量 更大,对水环境的不利影响远远高于水田.

\section{5 参考文献}

[ 1 ] Vitousek PJ, Aber JD, Howarth RW et al. Human alternation of the global nitrogen cycle: sources and consequences. Ecological Applications, 1997, 7(3):737-750.

[2] 田玉华,贺发云, 尹 斌等. 不同氮磷配合下稻田田面水的氮磷动态变化研究.土壤,2006,38(6):727-733.

[3] 汪 涛,朱 波,武永释等. 不同施肥制度下紫色土坡耕地氮素流失特征. 水土保持学报,2005,19(5):65-68. 
[ 4 ] 胡云才, Schmìdhalter U. 德国施肥法的特点和对我国的启示. 磷肥与复肥, 2005,20(3):6-8.

[ 5 ] OECD/EURO STAT. Gross Nitrogen Balances. Handbook. 2003. http://webdomino1. oecd. org/comnet/agr/aeiquest. nsf.

[6] Parris K. Agricultural nutrient balances as agri-environmental indicators: an OECD perspective. Environ Pollut, 1998, 102 : 219-225.

[ 7 ] Salo T, Turtola E. Nitrogen balance as an indicator of nitrogen leaching in Finland. Agriculture, Ecosystems and Environment, 2006, $113: 98-107$.

[ 8 ] Jerzy Kopiński, Arkadiusz Tujaka, Janusz Igras. Nitrogen and phosphorus budgets in Poland as a tool for sustainable nutrients management. Acta Agriculturae Slovenica, 2006, 87 (1) : 173-181.

[ 9 ] Bouwman AF, Van Drecht G, Vander Hoek KW. Global and regional surface nitrogen balances in intensive agricultural production systems for the period 1970-2030. Pedosphere,2005, 15(2) :137-155.

[10］邓美华,谢迎新,熊正琴等. 长江三角洲氮收支的估算及其环境影响. 环境科学学报,2007,10:1709-1716.

[11] 周扬明,于秀波, 鄢帮有. 1949-2005 年江西省农田养分平衡动态的宏观分析. 江西大学学报,2008,10:919-926.

[12] 黄进宝, 葛高飞, 范晓晖. 太湖地区麦季氨挥发与氮素利用的研究. 安徽农业大学学报,2009,36(4):677-682.

[13］沈善敏,刘鸿翔. 农业生态系统养分循环再利用作物产量增益的地理分异. 应用生态学报, 1998, (4):379-385.

[14] 张 璐, 沈善敏, 宇万太. 辽西褐土施肥及养分循环再利用中长期试验 IV : 土壤肥力变化. 应用生态学报, 2002,13 (11) :1413-1416.

[15] 鲁如坤, 时正元,赖庆旺. 红壤养分退化研究 III : 土壤和植株的养分淋失.土壤通报,2000,31(4):156-159.

[16] Xing GX, Zhu ZL. An assessment of $\mathrm{N}$ loss from agricultural fields to the environment in China. Nutrient Cycling in Agroecosystems, 2000, 57: 67-73.

[17] Xing GX, Zhu ZL. Regional nitrogen budgets for China and its major watersheds. Biogeochemistry, 2002, 57/58: $405-427$.

[18] 陈 辉,洪 伟,兰 斌等. 闽北毛竹生物量与生产力的研究. 林业科学, 1998,5(1):60-64.

[19] 孙 纲. 安徽肖坑天然毛竹林生产力及养分特征的研究 [学位论文]. 合肥: 安徽农业大学, 2009:5.

[20] 项文化,田大伦. 不同年龄阶段马尾松人工林养分循环的研究. 植物生态学报,2002,26(1):89-95.

[21] 莫江明, Brown S, 孔国辉. 鼎湖山马尾松林营养元素的分布和生物循环特征. 生态学报, 1999,9:635-640.

[22] 叶 川, 贺湘逸, 熊果跟. 丘陵红壤泡桐-茶树复合系统根系与调落物的研究. 江西农业学报, 1998,10(2):27-32.

[23] 方运霆,莫江明, Gundersen P 等. 森林土壤氮素转换及其对氮沉降的响应. 生态学报,2004,7:1523-1531.

[24] 郗金标,张福锁,有祥亮. 中国森林生态系统 N 平衡现状. 生态学报,2007,8:3258-3267.

[25] 朱兆良. 中国土壤氮素. 南京: 江苏科技出版社, 1992:123.

[26] 林 华. 固氮植物对竹林土壤条件的改善作用. 林业科技开发,2002,16(6): 17-19.

[27] 高利伟,马 林, 张卫峰等. 中国作物秸秆养分资源数量估算极其利用状况. 农业工程学报, 2009,25(7):173-179.

[28] 宋勇生,范晓晖,林德喜等. 太湖地区稻田氨挥发及影响因素的研究. 土壤学报, 2004,3:265-269.

[29］周 伟,田玉华,尹 斌. 太湖地区水稻追肥的氨挥发损失和氮素平衡. 中国生态农业学报,2011,19(1):32-36.

[30] 苏成国. 太湖地区稻麦轮作下农田的氨挥发损失与大气湿沉降的研究 [ 学位论文]. 南京: 南京农业大学,2004.

[31] 梁国庆, 周 卫, 夏文建. 优化施氮条件下冬小麦-夏玉米轮作农田氮素循环与平衡研究. 植物营养与肥料学报, $2010,16(2): 304-311$.

[32］于克伟, 陈冠雄. 农田和森林土壤中氧化亚氮的产生与还原. 应用生态学报,2000,6:385-389.

[33] 李永夫, 蒋培申, 刘 娟等. 施肥对毛竹林土壤水溶性有机碳氮与温室气体排放的影响. 林业科学, 2010,12: 166-170.

[34] 刘 惠,赵 平.华南丘陵区针叶林和果园地表 $\mathrm{N}_{2} \mathrm{O}$ 通量的日变化.生态环境,2008,17(3):1116-1119.

[35] OECD/OCDE. IPCC(1996) Guidelines for National Greenhouse Gas Inventories. In:Paris Loye-pilot MD, Morelli J eds. Fluctuations of ionic composition of precipitations collected in Corsica related to changes in the origins of incoming aerosols. J Aerosol Science, 1988, 19: 577-585.

[36] 朱兆良.农田中氮肥的损失与对策.土壤与环境,2000,9(1):1-6.

[37] 石孝均. 水旱轮作体系中的养分循环特征 [学位论文]. 北京: 中国农业大学, 2003 .

[38］高志勤. 毛竹林土壤磷、钾养分状况及生长效应. 南京林业大学学报: 自然科学版,2010,34(6):33-37.

[39] 刘西军, 黄庆丰, 聂昌伟等. 肖坑不同森林类型土壤氮、磷研究. 安徽农业大学学报, 2008,35 (1):124-127. 